\title{
Systemic Sclerosis: Highlighting Respiratory Complications and Significance of Early Screening
}

Naqvi Syed Gaggatur ${ }^{1}$, Aliya H. Sange ${ }^{2}$, Natasha Srinivas ${ }^{3}$, Mubashira K. Sarnaik ${ }^{1}$, Srimy Modi ${ }^{2}$, Yasaswi Pisipati $^{1}$, Sarayoo Vaidya ${ }^{1}$, Ibrahim Sange ${ }^{4,5}$

1. Internal Medicine, M. S. Ramaiah Medical College, Bangalore, IND 2. Research, K. J. Somaiya Medical College, Mumbai, IND 3. Research, B. G. S. Global Institute of Medical Sciences, Bangalore, IND 4. Research, California Institute of Behavioral Neurosciences \& Psychology, Fairfield, USA 5. Medicine, K. J. Somaiya Medical College, Mumbai, IND

Corresponding author: Naqvi Syed Gaggatur, naqvigs@gmail.com

\begin{abstract}
Systemic sclerosis (SSc) is an autoimmune disease that leads the patient to have a diverse clinical presentation encompassing several systems and a worse prognosis, mainly when complications arise. Most SSc-related deaths are caused by pulmonary hypertension (PH) and interstitial lung disease (ILD). This article focuses on pulmonary artery hypertension $(\mathrm{PAH})$ and ILD as pulmonary consequences of SSc. We examined the grave effects regarding SSc's respiratory complications, which are concealed by the disease's clinical heterogeneity. In this article, we briefly reviewed the discussion of clinical features and management and the mortality associated with the sequelae. We further addressed the benefits and significance of screening for the disease and associated respiratory complications in SSc patients in this study.
\end{abstract}

Review began 07/29/2021 Review ended 08/06/2021 Published 08/18/2021

๑) Copyright 2021 Syed Gaggatur et al. This is an open access article distributed under the terms of the Creative Commons Attribution License CC-BY 4.0., which permits unrestricted use, distribution, and reproduction in any medium, provided the original author and source are credited.
Categories: Internal Medicine, Pulmonology, Rheumatology

Keywords: systemic sclerosis, pulmonary artery hypertension, interstitial lung disease, respiratory complications, screening and diagnosis, prognosis, mortality, pulmonary artery vasoconstriction, vascular remodeling, thrombosis

\section{Introduction And Background}

Systemic sclerosis is an autoimmune disease that continues to challenge the medical fraternity due to its disparate nature [1]. A disease hallmarked by eventual fibrosis of the skin and the organ systems preceded pathologically always by the sequela of endothelial dysfunction resulting in disruption of the small vessel vasculature, immunological, and fibroblast dysfunction [1].

SSc is an uncommon autoimmune disease with a high case-specific mortality rate and an annual incidence of roughly 20 cases per million [2,3]. According to several studies, the incidence is higher and the prognosis is worse in African Americans as compared to Caucasians with a higher preponderance in females [2-5]. Other risk factors include Raynaud's phenomenon, steroid hormone imbalance, and selected chemical and thermal injuries [6]. The disease is characterized by a specific or functional antibody production as a response to a complex innate and adaptive immunity and involves complex pathogenesis comprising of vascular and immune dysregulation, which is inadequately comprehended [7]. The diffuse evolution of SSc involves progenitor-circulating cells such as monocytes and fibrocytes and the participation of growth factors and cytokines [7].

SSc has a diverse clinical presentation involving the skin and organs such as the lungs, heart, gastrointestinal tract, and kidneys [8]. Based on the amount of skin fibrosis involved, SSc is classified into limited cutaneous systemic sclerosis (lcSSc) or diffuse cutaneous systemic sclerosis (dsSSc) [8]. 1cSSc presents with fibrosis of the skin involving the peripheral parts of the body, face, and limbs (distal to the knees and elbows), whereas dsSSc presents with fibrosis of the trunk and proximal parts of the limbs [9]. The workup of the disease is specific to the system or phenotype predominantly involved. The frequently detected antibodies are antinuclear antibodies (ANA) and autoantibodies against topoisomerase I (Topo I, also known as ATA or Scl-70) [9]. The management of this disorder is hindered by its miscellaneous presentation and an unfavorable prognostic course [10].

Most deaths are due to the complications caused by PH and interstitial lung disease (ILD) as the involvement impacts all elements of the respiratory system, including the parenchyma, muscle, and vasculature, and can occur in both categories of the disease [11-13]. SSc-associated ILD is a dreaded complication that has risen to the top of the SSc-related causes of mortality, accounting for 35\% of all disease-related deaths [13]. Similarly, PAH, the other major complication of SSc, affects about $10 \%$ of the population [14]. Despite recent breakthroughs in treatment, the survival rates for the above complications remain dismal, especially for SScPAH patients with a median survival period of only three years $[13,14]$. Given such poor long-term outcomes, it is logical and imperative to screen early disease manifestations in the aforementioned illnesses. Albeit, according to new research, early screening programs in SSc and ILD can detect patients with milder forms of the disease, allowing for early therapeutic intervention and improved survival [13-15]. 


\section{Cureus}

This review article aims to:

1. Emphasize the growing concern about SSc's life-threatening complications, which are masked by the disease's clinical heterogeneity.

2. Evaluate the importance and highlight the benefits of early screening of ILD and PAH in SSc.

\section{Review}

The fundamental concern of researchers looking into mortality associated with systemic sclerosis (SSc) is progressive pulmonary deterioration since pulmonary complications have replaced scleroderma renal crisis as the primary cause of SSc-related death [16]. SSc can cause anything from minor parenchymal fibrosis to severe progressive ILD or isolated PH in the lungs, which can escalate to $\mathrm{PH}$ and aggravate the problem [17]. ILD and pulmonary arterial hypertension (PAH) are the leading causes of death in patients with systemic autoimmune disorders like SSc [18].

\section{Systemic sclerosis-associated pulmonary arterial hypertension (SSc- PAH)}

The World Health Organization (WHO) divided PH into groups based on the disease's pathogenesis, with group 1 being referred to as PAH [19]. PAH is defined as a mean pulmonary arterial pressure (mPAP) $\geqslant 25 \mathrm{~mm}$ $\mathrm{Hg}$ at rest, a mean pulmonary-capillary wedge pressure or left ventricular end-diastolic pressure $\leqslant 15 \mathrm{~mm}$ $\mathrm{Hg}$, and a pulmonary vascular resistance (PVR) $\geqslant 3$ Wood units (WU) [19]. PAH is a dreaded complication as it has high mortality and morbidity rates, especially as a complication in SSc, affecting $8 \%-15 \%$ of the SSc patients $[20,21]$.

Manifestations of PAH are due to the combined actions of pulmonary artery vasoconstriction, vascular remodeling, and thrombosis that cause a prolonged increase in PVR and pulmonary arterial pressure (PAP) [22]. The pathophysiological mechanism is that all the sheaths of the vessel wall and all the cell types that make up the vessel wall are involved in vascular remodeling (endothelial cells, smooth muscle cells, fibroblasts, inflammatory cells, and platelets) [22]. Growth, apoptosis, mild inflammation, vascular ions, and fibrosis are dynamic processes that might affect the level of remodeling [22]. The deficiency of potassium channel expression and endothelial dysfunction has been linked to excessive vasoconstriction [22]. These effects further culminate in chronic insufficiency of vasodilators, such as nitrogen monoxide and prostacyclin, and overproduction of vasoconstrictors, such as endothelin-1 [22]. The overproduction of vasoconstrictors leads to chronic vasoconstriction, eventually resulting in smooth muscle hypertrophy and endothelial proliferation, culminating in a narrow vascular lumen with increased pressure [23].

At the time of diagnosis, most patients present with severe signs and symptoms, including dyspnea, hemoptysis, or syncope, and considerable functional impairment often associated with severe hemodynamics (Figure 1) [24]. Right heart catheterization is used as a standard for diagnosing PH, and echocardiography is the screening tool where the tricuspid regurgitation velocity (TRV) and right atrial pressure are used as determinants [25]. After undergoing the initial screening, patients who tested positive for the disease underwent a right heart catheterization to confirm the diagnosis [26]. 


\section{Cureus}

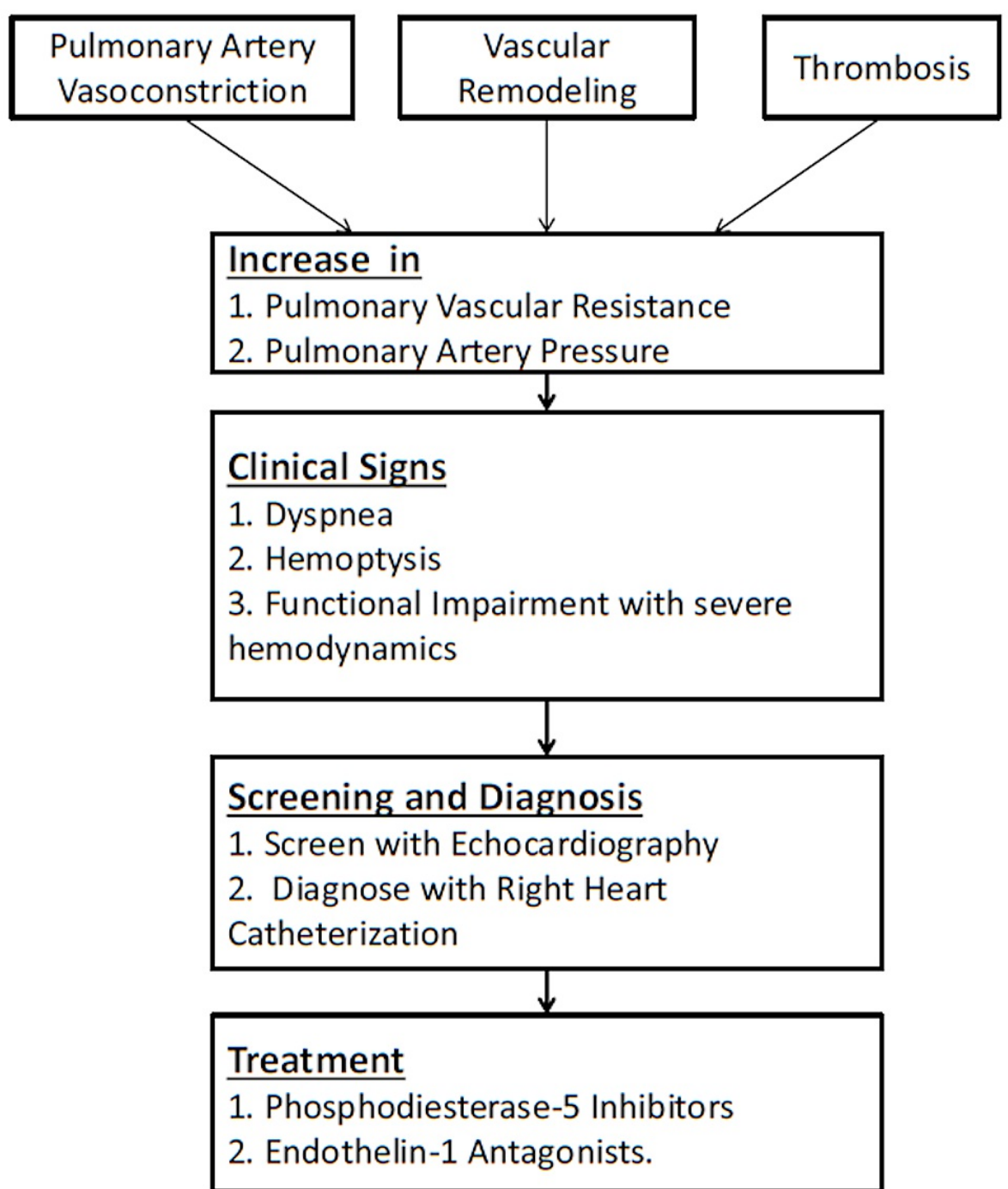

FIGURE 1: Summary of pathogenesis, investigation, and management of pulmonary artery hypertension (PAH) in systemic sclerosis (SSc), SScPAH

Experts continue to believe that phosphodiesterase 5 (PDE5) inhibitors, endothelin receptor antagonists with PDE5 inhibitors, and prostanoids are the best therapy for mild cases of PAH [27]. For severe cases, prostanoids are the first line of treatment [27]. Drugs such as sildenafil, a phosphodiesterase-5 (PDE-5) inhibitor, has demonstrated an increased exercise tolerance in patients with $\mathrm{PH}$ when used in the treatment of SSc-PAH [28]. Similar improvements in efficacy were seen with bosentan, an endothelin-1 receptor antagonist [29]. The addition of epoprostenol, a potent, short-acting vasodilator, tends to improve the sixminute walk distance and lower PVR in PH patients [30].

PAH is a feared complication, affecting around $8 \%-15 \%$ of SSc patients $[20,21]$. Any delay in diagnosing PAH in SSc patients will lead to poor prognosis; hence, studies recommending early detection and immediate treatment are critical for successful management with better prognostic outcomes [31] (Table 1). 


\section{Cureus}

\begin{tabular}{|c|c|c|c|c|}
\hline References & Design & $\begin{array}{l}\text { Cases } \\
\text { of SSc- } \\
\text { PAH }\end{array}$ & $\begin{array}{l}\text { Study } \\
\text { parameters }\end{array}$ & Conclusion \\
\hline $\begin{array}{l}\text { Morrisroe } \\
\text { et al. } \\
\text { (2016) [34] }\end{array}$ & $\begin{array}{l}\text { Cohort } \\
\text { study }\end{array}$ & $\begin{array}{l}132 \\
\text { (Total } \\
\text { cases of } \\
\text { SSc was } \\
1579 .)\end{array}$ & $\begin{array}{l}\text { Incidence, } \\
\text { prevalence, } \\
\text { and risk } \\
\text { factors }\end{array}$ & $\begin{array}{l}\text { PAH is the leading cause of SSc-related deaths. SSc-PAH is connected to mild } \\
\text { ILD in both categories. Early diagnosis and treatment of PAH in SSc patients } \\
\text { might improve their prognosis. }\end{array}$ \\
\hline $\begin{array}{l}\text { Chung et } \\
\text { al. } \\
\text { (2014) [31] }\end{array}$ & $\begin{array}{l}\text { Prospective } \\
\text { multicenter } \\
\text { cohort }\end{array}$ & 131 & $\begin{array}{l}\text { Survival } \\
\text { rates and } \\
\text { mortality } \\
\text { predictors }\end{array}$ & $\begin{array}{l}\text { With the routine screening of PAH in SSc-PAH patients, the survival rates were } \\
\text { better than those reported in similar cohorts. The patients with severely } \\
\text { reduced DLCO and NYHA FC IV status at the time of PAH diagnosis had a } \\
\text { dismal prognosis. }\end{array}$ \\
\hline $\begin{array}{l}\text { Launay et } \\
\text { al. } \\
\text { (2013) [32] }\end{array}$ & $\begin{array}{l}\text { Prospective } \\
\text { multicenter } \\
\text { cohort }\end{array}$ & 85 & $\begin{array}{l}\text { Survival } \\
\text { and } \\
\text { Prognostic } \\
\text { Factors }\end{array}$ & $\begin{array}{l}\text { Even with modern medical advancements, incident SSc-associated PAH } \\
\text { continues to be a terrible disease. In this group of patients, age, male gender, } \\
\text { and cardiac index were the most important prognostic markers. Early diagnosis } \\
\text { of PAH in SSc patients should be a top concern. }\end{array}$ \\
\hline
\end{tabular}

\section{TABLE 1: Summary of included studies linking PAH and SSc}

DLCO, Diffusing capacity of the lungs for carbon monoxide; ILD, interstitial lung disease; NYHA FC, New York Heart Association Functional Classification; PAH, pulmonary arterial hypertension; SSc, systemic sclerosis; SSc-PAH, systemic sclerosis-associated pulmonary arterial hypertension.

A cohort study was performed in 2016 on a group of adults in Australia, which aimed to determine the incidence, prevalence, and risk factors for the development of PAH in SSc. In the study, out of 1579 cases of SSc, 132 cases were diagnosed to have SSc-PAH using right heart catheterization. The study concluded that $\mathrm{PAH}$ is the leading cause of SSc-related death, and SSc-PAH is connected to mild ILD in both subtypes. The study also emphasized that early diagnosis and treatment of PAH in SSc patients may improve their prognosis (Table 1) [31].

In another prospective multicentric cohort study done in the United States, 131 SSc-PAH patients were diagnosed using right heart catheterization as a criterion and studied. The study indicated that the survival rates were better when compared to other similar cohorts and highlighted the need for early screening and diagnosis of PAH in SSc as the prognosis is dismal on delayed diagnosis (Table 1) [32].

Similarly, another study was conducted by Launay et al. in 2013 in France, where 85 patients were diagnosed with SSc-PAH and examined for survival and prognostic factors. The study concluded that the presence of $\mathrm{PAH}$ in SSc patients is associated with increased mortality rates, especially in the elderly and male gender (Table 1) [33]. Hence it is critical to use early screening procedures to detect PAH in patients with SSc through routine systematic screening of asymptomatic patients. It will lead to earlier diagnosis, improved survival rates, and prognosis $[32,33]$.

The existing annual screening protocols that are recommended utilize algorithms that comprise a transthoracic echocardiogram (TTE) and pulmonary function tests (PFTs) [34]. Screening by DETECT algorithm, pulmonary function testing (forced vital capacity/diffusing capacity of the lung for carbon monoxide ratio), and N-terminal-pro-brain natriuretic peptide levels are also used as alternatives [35]. Other screening modalities are exercise echocardiography, also known as cardiopulmonary exercise testing, nailfold capillaroscopy, and molecular biomarkers [24]. Identification of the true predictive values for PAH can include systematic catheterization in future screening studies [24]. As a guideline, symptomatic patients with a high TRV with or without secondary echocardiographic signs of PAH or those who test positive on the DETECT algorithm or other pulmonary function test algorithms should undergo right heart catheterization [24].

\section{Systemic sclerosis-associated interstitial lung disease (SSc-ILD)}

ILD signifies a wide range of illnesses defined by improper gas exchange due to changes in the interstitial region of the lung's architecture. ILD was predicted to have a yearly incidence of 30 per 100000 people, with a female preponderance and a three-year average survival [35]. It occurs due to endogenous or exogenous causes, including environmental exposures, autoimmune diseases, infections, drugs, and radiation, with most cases being idiopathic. ILD can manifest as a dreaded complication in systemic sclerosis patients [13] as it does in $25 \%-30 \%$ of SSc patients with lung fibrosis [36]. 
Anti-Scl-70 antibodies, diffuse cutaneous SSc, African-American race, older age, and shorter disease duration have all been major risk factors for the development of SSc-ILD, according to observational studies [37-39]. Considering the pathophysiology behind SSc-ILD, involving tissue hypoxia and vascular hyperreactivity, there are abnormal interactions between endothelial cells, lymphocytes, monocytes, and fibroblasts resulting in excess of extracellular matrix formation by fibroblasts (Figure 2) [40]. Also, antifibroblast antibodies have been found to activate fibroblasts and stimulate extracellular matrix synthesis [41]. Pro-inflammatory cytokines interleukin-8 (IL-8), tumor necrosis factor-a (TNF-a), and macrophage inflammatory protein-1 were found to be elevated [42]. Patients with SSc-ILD have greater levels of antitopoisomerase and anti-fibroblast antibodies, suggesting that B-cells may be implicated [43,44].

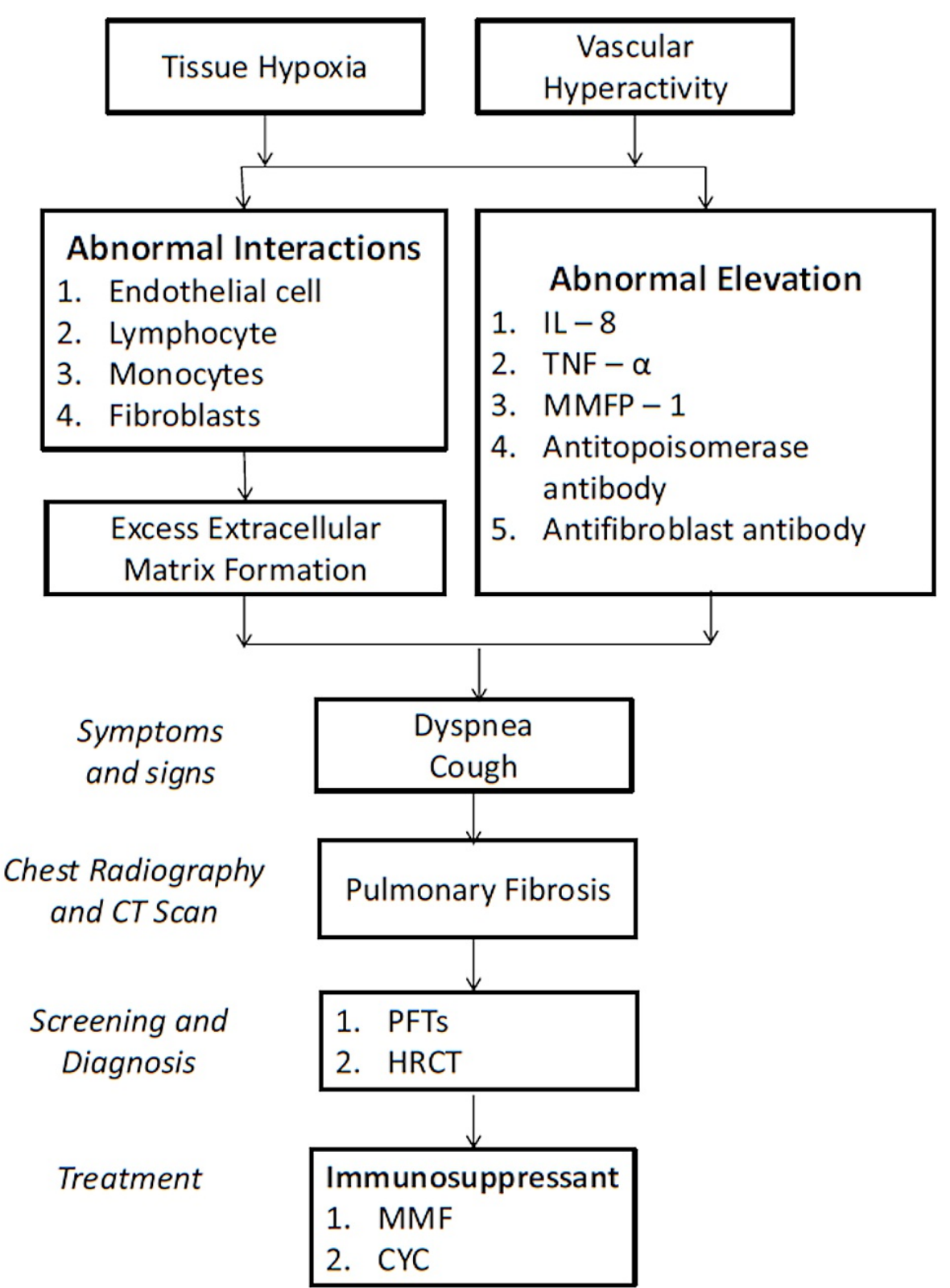

FIGURE 2: Summary of etiology, clinical features, and management of interstitial lung disease (ILD) in systemic sclerosis (SSc), SSc-ILD

SSc has multiple manifestations clinically with dyspnea, cough, and a non-specific interstitial pneumonia pattern on computerized tomography (CT) scan as the most prevalent signs of systemic sclerosis-associated ILD, with only a small percentage of cases meeting the criteria for typical interstitial pneumonia [45]. SScILD usually presents with pronounced pulmonary fibrosis in basilar portions of the lungs when seen on high-resolution CT (HRCT) or chest radiographs [46]. When evaluated, the radiographic extent of the disease and the likelihood of progression are two methods of many used for classifying SSc-ILD. Goh et al. created a 
categorization system to assess the severity of ILD in SSc in 2008 [41]. They divided patients into limited and extensive disease categories using a combination of HRCT and PFTs [47]. Patients with SSc-ILD can also be divided into groups based on disease progression [48]. Patients with a slow, gradual reduction in forced vital capacity (FVC) or stability and those with a fast progressive clinical picture will require lung transplantation or progress to eventual death regardless of therapy [48]. The disease's clinical presentation is varied and requires a thorough clinical analysis [48].

A comprehensive diagnosis becomes necessary for evaluating SSc patients based on the heterogeneous presentation of this disease [49]. Spirometry and single-breath carbon monoxide diffusion capacity (DLCO) are among the pulmonary function tests (PFTs) exclusively used in the diagnostic workup [49]. Minor alterations in lung function can be identified early, which helps determine the respiratory pattern before symptoms or chest radiography changes can arise [49]. The most prevalent alteration in PFTs is a lower FVC with normal or even increased volume that has been exhaled at the end of the first second of forced expiration (FEV1)/FVC ratio, indicating a restrictive ventilatory pattern [49]. Similarly, HRCT is a noninvasive method of diagnosing ILD since it can determine the nature and degree of pulmonary involvement [49].

On the evaluation of various therapeutic choices, immunosuppressants, particularly mycophenolate mofetil (MMF) or cyclophosphamide (CYC), have typically been the standard treatment [45]. When the two drugs were compared, MMF was better tolerated than CYC, as documented in the Scleroderma Lung Study II [50]. The researchers looked at 142 patients with SSc-ILD who had an FVC of 80\% with ground glass opacities on HRCT [50]. The study concluded that MMF had a decreased incidence of leukopenia and thrombocytopenia, making it the first choice of treatment over CYC [50]. Based on the Scleroderma Lung Study II results, CYC is considered an alternative to MMF, comparable to earlier research [50]. Even though targeted biological and antifibrotic therapy can be used in addition to immunosuppressants [45], refractory cases still must be treated with autologous hematopoietic stem cell transplantation and lung transplantation [45].

Early screening is critical for SSc patients with ILD [51] since they tend to have comorbidities (Table 2) [52]. For the effective therapy of SSc-ILD patients, earlier detection and screening of pulmonary disease based on a recent reduction in lung function tests and the degree of lung involvement at high-resolution computed tomography become imperative [51]. The screening guidelines encompass a thorough examination of systems, a complete physical examination, a complete assessment of PFTs with lung volumes, and lung imaging with HRCT [51]. In a cohort study performed in the United States, on analysis of the incidence, prevalence, patient profile, immunosuppressive therapy (IST), and comorbid outcomes, it was found that out of 34,820 cases of SSc, 8252 cases of SSc-ILD were diagnosed. The study concluded that patients with SScILD received more IST and had more significant comorbidities when compared to newly diagnosed SSc patients [52] (Table 2). 


\section{Cureus}

\begin{tabular}{|c|c|c|c|c|c|c|}
\hline References & Design & $\begin{array}{l}\text { Total } \\
\text { cases } \\
\text { of SSc }\end{array}$ & $\begin{array}{l}\text { Cases } \\
\text { of } \\
\text { SSc- } \\
\text { ILD }\end{array}$ & Study parameters & Diagnostic criteria & Conclusion \\
\hline $\begin{array}{l}\text { Li et al. } \\
\text { (2021) [48] }\end{array}$ & $\begin{array}{l}\text { Cohort } \\
\text { study }\end{array}$ & 34,820 & 8252 & $\begin{array}{l}\text { Incidence, prevalence, } \\
\text { patient characteristics, } \\
\text { immunosuppressive } \\
\text { therapy (IST), and } \\
\text { comorbid outcomes }\end{array}$ & $\begin{array}{l}\text { In the SSc cohort, patients had one } \\
\text { or more SSc diagnostic claims. } \\
\text { Patients in the SSc-ILD cohort had } \\
\text { an additional ILD claim. }\end{array}$ & $\begin{array}{l}\text { In comparison to freshly } \\
\text { diagnosed SSc, } \\
\text { patients with SSc-ILD } \\
\text { received more IST and } \\
\text { had greater } \\
\text { comorbidities. }\end{array}$ \\
\hline $\begin{array}{l}\text { Showalter } \\
\text { et al. } \\
\text { (2018) [52] }\end{array}$ & $\begin{array}{l}\text { Cohort } \\
\text { study }\end{array}$ & 265 & 188 & $\begin{array}{l}\text { Sensitivity, specificity, } \\
\text { and negative } \\
\text { predictive value (NPV) } \\
\text { of FVC and DLCO } \\
\text { thresholds for SSc-ILD } \\
\text { on HRCT }\end{array}$ & $\begin{array}{l}\text { American College of Rheumatology } \\
2013 \text { SSc criteria with a chest HRCT } \\
\text { scan and pulmonary function tests } \\
\text { (PFT). FVC }<80 \% \text { and DLCO }<62 \% \\
\text { for radiographic SSc-ILD. }\end{array}$ & $\begin{array}{l}\text { High prevalence of } \\
\text { radiographic ILD in SSc } \\
\text { despite normal PFT } \\
\text { values. }\end{array}$ \\
\hline $\begin{array}{l}\text { Sánchez- } \\
\text { Cano et al. } \\
\text { (2018) [53] }\end{array}$ & $\begin{array}{l}\text { Descriptive } \\
\text { multicentric } \\
\text { cohort }\end{array}$ & 1374 & 595 & $\begin{array}{l}\text { Clinical } \\
\text { characteristics, } \\
\text { differences according } \\
\text { to the subtypes, } \\
\text { mortality, and } \\
\text { morbidity }\end{array}$ & $\begin{array}{l}\text { The modified classification criteria } \\
\text { of the American College of } \\
\text { Rheumatology for SSc proposed by } \\
\text { LeRoy and Medsger }\end{array}$ & $\begin{array}{l}\text { ILD as a complication } \\
\text { of SSc has significant } \\
\text { morbidity and mortality } \\
\text { in all three subgroups. }\end{array}$ \\
\hline
\end{tabular}

TABLE 2: Summary of included studies linking ILD and SSc.

SSc, Systemic sclerosis; SSc-ILD, systemic sclerosis-associated interstitial lung disease; ILD, interstitial lung disease; IST, immunosuppressive therapy; NPV, negative predictive value; FVC, forced vital capacity; DLCO, single-breath carbon monoxide diffusion capacity; HRCT, high-resolution $\mathrm{CT}$; PFT, pulmonary function test.

With many studies describing the poor prognosis of SSc-ILD, there are many challenges we face in addressing the problem. There is a lack of consensus on ILD screening or disease progression monitoring despite the well-established link between SSc-ILD and mortality [54]. There is a lack of proven biomarkers for SSc-ILD and clinical recommendations to guide the methodology of investigations for diagnosis and identification of those at risk of progression [55]. ILD associated with pulmonary artery hypertension (ILDPAH) patients had a worse five-year survival rate than SSc-PAH and SSc-ILD patients, with PAH being the only factor connected to an increased risk of mortality (Table 3) [56]. A substantial proportion of patients with SSc-related ILD also had PAH, making it critical to search for PAH in SSc-ILD patients (Table 3) [57]. Survival in SSc-PAH patients is poor, and SSc patients with ILD-related PAH have an even worse prognosis (Table 3) [58]. Patients with SSc-ILD or SSc-PAH have a poor prognosis, but the combination of ILD-PAH has the worst prognosis (Figure 3). Based on this analysis, a multidimensional approach to SSc-ILD should be devised, enabling early detection of ILD in SSc patients for timely intervention and a change in the disease trajectory. 


\section{Cureus}

\begin{tabular}{|c|c|c|c|c|c|c|c|c|}
\hline \multirow[t]{2}{*}{ References } & Design & $\begin{array}{l}\text { Total } \\
\text { cases } \\
\text { of } \\
\text { SSc }\end{array}$ & $\begin{array}{l}\text { Cases } \\
\text { of } \\
\text { SSc }\end{array}$ & $\begin{array}{l}\text { Cases } \\
\text { of } \\
\text { ssc }\end{array}$ & $\begin{array}{l}\text { Cases } \\
\text { of } \\
\text { ssc }\end{array}$ & $\begin{array}{l}\text { Study } \\
\text { parameters }\end{array}$ & Diagnostic criteria & Conclusion \\
\hline & & & PAH & ILD & $\begin{array}{l}\text { (ILD- } \\
\text { PAH) }\end{array}$ & & & \\
\hline $\begin{array}{l}\text { Noviani et } \\
\text { al. (2020) [55] }\end{array}$ & Cohort study & 490 & 50 & 92 & 43 & $\begin{array}{l}\text { Mortality and } \\
\text { survival }\end{array}$ & $\begin{array}{l}\text { For ILD - HRCT - significant ILD } \\
\text { - FVC }<70 \% \text { predicted PAH - } \\
\text { echo (sPAP) } \geq 50 \mathrm{mmHg} \text { or RHC } \\
\text { with mean PAP } \geq 25 \mathrm{mmHg} \text {. For } \\
\text { mortality -multivariable } \\
\text { regression analyses for survival } \\
\text { - Cox proportional hazard } \\
\text { model. }\end{array}$ & $\begin{array}{l}\text { ILD-PH patients exhibited } \\
\text { a lower five-year survival } \\
\text { rate than SSc-PAH and } \\
\text { SSc-ILD patients. Only } \\
\text { PAH was linked to an } \\
\text { increased risk of death on } \\
\text { its own. }\end{array}$ \\
\hline $\begin{array}{l}\text { Young et al. } \\
\text { (2019) [56] }\end{array}$ & $\begin{array}{l}\text { Prospective } \\
\text { observational } \\
\text { cohort }\end{array}$ & 93 & 50 & 24 & 29 & $\begin{array}{l}\text { Prevalence, } \\
\text { characteristics, } \\
\text { treatment, and } \\
\text { outcomes }\end{array}$ & $\begin{array}{l}\text { For PAH - right heart } \\
\text { catheterization. For survival - } \\
\text { Kaplan-Meier method was used. }\end{array}$ & $\begin{array}{l}\text { A large proportion of } \\
\text { patients with SSc-related } \\
\text { ILD also had PH. Patients } \\
\text { with SSc-related ILD } \\
\text { should be investigated for } \\
\text { PH as well. }\end{array}$ \\
\hline $\begin{array}{l}\text { Mathai et al. } \\
\text { (2009) [57] }\end{array}$ & Cohort study & 59 & 39 & - & 20 & $\begin{array}{l}\text { Determinants } \\
\text { of survival }\end{array}$ & $\begin{array}{l}\text { Right heart catheterization. } \\
\text { Kaplan-Meier and Cox } \\
\text { proportional hazards model }\end{array}$ & $\begin{array}{l}\text { In SSc patients with PAH, } \\
\text { survival is still dismal. SSc } \\
\text { patients with ILD-related } \\
\text { PAH have an especially } \\
\text { poor prognosis. Early } \\
\text { diagnosis and treatment } \\
\text { may improve outcomes. }\end{array}$ \\
\hline $\begin{array}{l}\text { PAH, Pulmonar } \\
\text { disease; ILD-PA } \\
\text { mPAP, mean pu } \\
\text { hypertension. }\end{array}$ & $\begin{array}{l}\text { y arterial hyperte } \\
\text { AH, ILD associate } \\
\text { Imonary arterial }\end{array}$ & $\begin{array}{l}\text { nsion; } \\
\text { pressure }\end{array}$ & ; PAH, $p$ & $\begin{array}{l}\text { mic scle } \\
\text { T, high-1 } \\
\text { ulmonan }\end{array}$ & $\begin{array}{l}\text { osis; SSc } \\
\text { esolution } \\
\text { arterial } h\end{array}$ & $\begin{array}{l}\text {-ILD, systemic sc } \\
\text { CT; sPAP, systolic } \\
\text { ypertension; SSc- }\end{array}$ & $\begin{array}{l}\text { lerosis-associated interstitial lung } \\
\text { pulmonary artery pressure; RHC, } \\
\text { PAH, systemic sclerosis-associate }\end{array}$ & $\begin{array}{l}\text { disease; ILD, interstitial lung } \\
\text { ight heart catheterization; } \\
\text { d pulmonary arterial }\end{array}$ \\
\hline
\end{tabular}




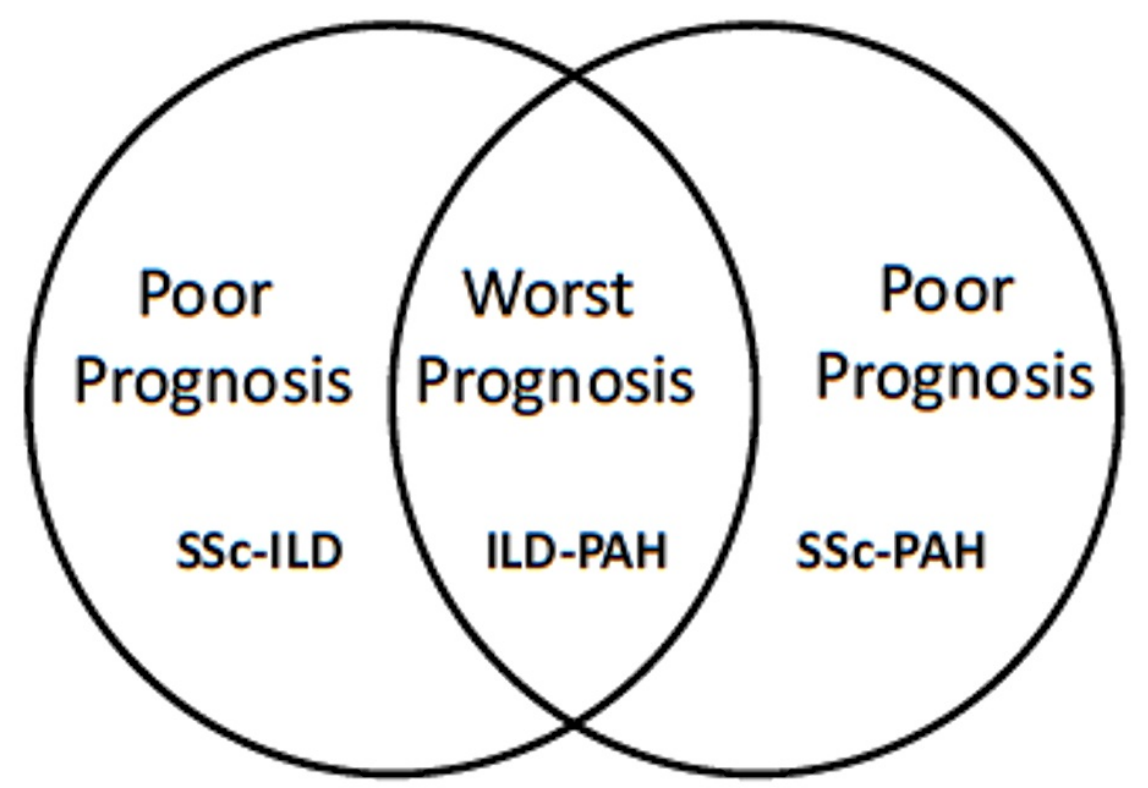

FIGURE 3: Prognosis of systemic sclerosis patients affected with ILD, PAH, and ILD associated with PAH (ILD-PAH).

ILD, Interstitial lung disease; PAH, pulmonary arterial hypertension; SSc, systemic sclerosis.

\section{Limitations of the study}

SSc has a complex network of etiologies with multiple underlying components. This article concentrates solely on SSC's respiratory problems for analysis and does not address other variables in the prognosis of this condition. Elevated pulmonary pressures in patients with SSc can be caused by various conditions, including PAH, parenchymal lung disease, and left heart disease. Not every one of them has been thoroughly investigated. Our article highlighted important studies for analysis but we were unable to address all of them.

\section{Conclusions}

As addressed in this article, patients with SSc have a complex multisystem involvement with a wide range of clinical manifestations. The respiratory complications of SSc, notably ILD and PAH, can occur separately and are closely linked together, as evidenced by research. Despite recent medical advances, these complications are associated with a significant risk of mortality and a dismal prognosis. As a result, both respiratory complications should be screened in SSc patients. We notably discussed the difficulties that physicians confront when dealing with these illnesses. This article, we believe, can underline the critical necessity of early diagnosis of the disease and its sequela to improve the outcome. It can be accomplished through a strict screening routine, widespread availability of screening instruments, and general awareness of these illnesses, all of which will help the patient recover more quickly and have a better long-term prognosis. Finally, we believe that more significant research into the link between SSc and the respiratory system is needed to develop a more coordinated and direct approach to diagnosing and treating these disorders.

\section{Additional Information}

\section{Disclosures}

Conflicts of interest: In compliance with the ICMJE uniform disclosure form, all authors declare the following: Payment/services info: All authors have declared that no financial support was received from any organization for the submitted work. Financial relationships: All authors have declared that they have no financial relationships at present or within the previous three years with any organizations that might have an interest in the submitted work. Other relationships: All authors have declared that there are no other relationships or activities that could appear to have influenced the submitted work.

\section{References}

1. Varga J, Trojanowska M, Kuwana M: Pathogenesis of systemic sclerosis: recent insights of molecular and cellular mechanisms and therapeutic opportunities. J Scleroderma Relat Disord. 2017, 2:137-52. 10.5301/jsrd.5000249 
2. Bryan C, Howard Y, Brennan P, Black C, Silman A: Survival following the onset of scleroderma: results from a retrospective inception cohort study of the UK patient population. Br J Rheumatol. 1996, 35:1122-6. 10.1093/rheumatology/35.11.1122

3. Mayes MD, Lacey JV Jr, Beebe-Dimmer J, Gillespie BW, Cooper B, Laing TJ, Schottenfeld D: Prevalence, incidence, survival, and disease characteristics of systemic sclerosis in a large US population. Arthritis Rheum. 2003, 48:2246-55. 10.1002/art.11073

4. Steen VD, Oddis CV, Conte CG, Janoski J, Casterline GZ, Medsger TA Jr: Incidence of systemic sclerosis in Allegheny County, Pennsylvania. A twenty-year study of hospital-diagnosed cases, 1963-1982. Arthritis Rheum. 1997, 40:441-5. 10.1002/art.1780400309

5. Laing TJ, Gillespie BW, Toth MB, et al.: Racial differences in scleroderma among women in Michigan . Arthritis Rheum. 1997, 40:734-42. 10.1002/art.1780400421

6. Cutolo M, Soldano S, Smith V: Pathophysiology of systemic sclerosis: current understanding and new insights. Expert Rev Clin Immunol. 2019, 15:753-64. 10.1080/1744666X.2019.1614915

7. Katsumoto TR, Whitfield ML, Connolly MK: The pathogenesis of systemic sclerosis . Annu Rev Pathol. 2011, 6:509-37. 10.1146/annurev-pathol-011110-130312

8. LeRoy EC, Medsger TA: Criteria for the classification of early systemic sclerosis . J Rheumatol. 2001, 28:15736.

9. Sobolewski P, Maślińska M, Wieczorek M, et al.: Systemic sclerosis - multidisciplinary disease: clinical features and treatment. Reumatologia. 2019, 57:221-33. 10.5114/reum.2019.87619

10. Nihtyanova SI, Ong VH, Denton CP: Current management strategies for systemic sclerosis . Clin Exp Rheumatol. 2014, 32:156-64.

11. Saygin D, Domsic RT: Pulmonary arterial hypertension In systemic sclerosis: challenges in diagnosis, screening and treatment. Open Access Rheumatol. 2019, 11:323-33. 10.2147/OARRR.S228234

12. Hoffmann-Vold AM, Fretheim H, Halse AK, et al.: Tracking ilmpact of interstitial lung disease in systemic sclerosis in a complete nationwide cohort. Am J Respir Crit Care Med. 2019, 200:1258-66. 10.1164/rccm.201903-04860C

13. Silver KC, Silver RM: Management of systemic-sclerosis-associated interstitial lung disease. Rheum Dis Clin North Am. 2015, 41:439-57. 10.1016/j.rdc.2015.04.006

14. Lefèvre G, Dauchet L, Hachulla E, et al.: Survival and prognostic factors in systemic sclerosis-associated pulmonary hypertension: a systematic review and meta-analysis. Arthritis Rheum. 2013, 65:2412-23. 10.1002/art.38029

15. Humbert M, Yaici A, de Groote P, et al.: Screening for pulmonary arterial hypertension in patients with systemic sclerosis: clinical characteristics at diagnosis and long-term survival. Arthritis Rheum. 2011, 63:3522-30. 10.1002/art.30541

16. Steen VD: The lung in systemic sclerosis . J Clin Rheumatol. 2005, 11:40-6. 10.1097/01.rhu.0000152147.38706.db

17. Trad S, Amoura Z, Beigelman C, et al.: Pulmonary arterial hypertension is a major mortality factor in diffuse systemic sclerosis, independent of interstitial lung disease. Arthritis Rheum. 2006, 54:184-91. 10.1002/art.21538

18. Simonneau G, Gatzoulis MA, Adatia I, et al.: Updated clinical classification of pulmonary hypertension. J Am Coll Cardiol. 2013, 62:D34-41. 10.1016/j.jacc.2013.10.029

19. Hao Y, Thakkar V, Stevens W, et al.: A comparison of the predictive accuracy of three screening models for pulmonary arterial hypertension in systemic sclerosis. Arthritis Res Ther. 2015, 17:7. 10.1186/s13075-0150517-5

20. Muangchan C, Baron M, Pope J: The 15\% rule in scleroderma: the frequency of severe organ complications in systemic sclerosis. A systematic review. J Rheumatol. 2013, 40:1545-56. 10.3899/jrheum.121380

21. D'Alonzo GE, Barst RJ, Ayres SM, et al.: Survival in patients with primary pulmonary hypertension. Results from a national prospective registry. Ann Intern Med. 1991, 115:343-9. 10.7326/0003-4819-115-5-343

22. Gurbanov E, Shiliang X: The key role of apoptosis in the pathogenesis and treatment of pulmonary hypertension. Eur J Cardiothorac Surg. 2006, 30:499-507. 10.1016/j.ejcts.2006.05.026

23. Jonigk D, Golpon H, Bockmeyer CL, et al.: Plexiform lesions in pulmonary arterial hypertension composition, architecture, and microenvironment. Am J Pathol. 2011, 179:167-79. 10.1016/j.ajpath.2011.03.040

24. Weatherald J, Montani D, Jevnikar M, Jaïs X, Savale L, Humbert M: Screening for pulmonary arterial hypertension in systemic sclerosis. Eur Respir Rev. 2019, 28:190023. 10.1183/16000617.0023-2019

25. Gordeuk VR, Castro OL, Machado RF: Pathophysiology and treatment of pulmonary hypertension in sickle cell disease. Blood. 2016, 127:820-8. 10.1182/blood-2015-08-618561

26. Parent F, Bachir D, Inamo J, et al.: A hemodynamic study of pulmonary hypertension in sickle cell disease . N Engl J Med. 2011, 365:44-53. 10.1056/NEJMoa1005565

27. Fernández-Codina A, Walker KM, Pope JE: Treatment algorithms for systemic sclerosis according to experts . Arthritis Rheumatol. 2018, 70:1820-8. 10.1002/art.40560

28. Machado RF, Martyr S, Kato GJ, et al.: Sildenafil therapy in patients with sickle cell disease and pulmonary hypertension. Br J Haematol. 2005, 130:445-53. 10.1111/j.1365-2141.2005.05625.x

29. Minniti CP, Machado RF, Coles WA, Sachdev V, Gladwin MT, Kato GJ: Endothelin receptor antagonists for pulmonary hypertension in adult patients with sickle cell disease. Br J Haematol. 2009, 147:737-43. 10.1111/j.1365-2141.2009.07906.x

30. Barst RJ, Rubin LJ, Long WA, et al.: A comparison of continuous intravenous epoprostenol (prostacyclin) with conventional therapy for primary pulmonary hypertension. N Engl J Med. 1996, 334:296-301. 10.1056/NEJM199602013340504

31. Chung L, Domsic RT, Lingala B, et al.: Survival and predictors of mortality in systemic sclerosis-associated pulmonary arterial hypertension: outcomes from the pulmonary hypertension assessment and recognition of outcomes in scleroderma registry. Arthritis Care Res (Hoboken). 2014, 66:489-95. 10.1002/acr.22121

32. Launay D, Sitbon O, Hachulla E, et al.: Survival in systemic sclerosis-associated pulmonary arterial hypertension in the modern management era. Ann Rheum Dis. 2013, 72:1940-6. 10.1136/annrheumdis- 
2012-202489

33. Coultas DB, Zumwalt RE, Black WC, Sobonya RE: The epidemiology of interstitial lung diseases. Am J Respir Crit Care Med. 1994, 150:967-72. 10.1164/ajrccm.150.4.7921471

34. Morrisroe K, Huq M, Stevens W, Rabusa C, Proudman SM, Nikpour M: Risk factors for development of pulmonary arterial hypertension in Australian systemic sclerosis patients: results from a large multicenter cohort study. BMC Pulm Med. 2016, 16:134. 10.1186/s12890-016-0296-z

35. Denton CP, Khanna D: Systemic sclerosis. Lancet. 2017, 7:1685-99. 10.1016/S0140-6736(17)30933-9

36. van den Hoogen F, Khanna D, Fransen J, et al.: 2013 classification criteria for systemic sclerosis: an American College of Rheumatology/European League against Rheumatism collaborative initiative. Arthritis Rheum. 2013, 65:2737-47. 10.1002/art.38098

37. Jaeger VK, Wirz EG, Allanore Y, et al.: Incidences and risk factors of organ manifestations in the early course of systemic sclerosis: a longitudinal EUSTAR study. PloS one. 2016, 5:0163894. 10.1371/journal.pone.0163894

38. Steen V, Domsic RT, Lucas M, Fertig N, Medsger TA Jr: A clinical and serologic comparison of African American and Caucasian patients with systemic sclerosis. Arthritis Rheum. 2012, 64:2986-94. 10.1002/art.34482

39. Tamby MC, Chanseaud Y, Guillevin L, Mouthon L: New insights into the pathogenesis of systemic sclerosis . Autoimmunity reviews. 2003, 2:152-7. 10.1016/s1568-9972(03)00004-1

40. Bolster MB, Ludwicka A, Sutherland SE, Strange C, Silver RM: Cytokine concentrations in bronchoalveolar lavage fluid of patients with systemic sclerosis. Arthritis Rheum. 1997, 40:743-51. 10.1002/art.1780400422

41. Goh NS, Desai SR, Veeraraghavan S, et al.: Interstitial lung disease in systemic sclerosis: a simple staging system. Am J Respir Crit Care Med. 2008, 177:1248-54. 10.1164/rccm.200706-8770C

42. Weiner ES, Earnshaw WC, Senécal JL, Bordwell B, Johnson P, Rothfield NF: Clinical associations of anticentromere antibodies and antibodies to topoisomerase I. A study of 355 patients. Arthritis Rheum. 1988, 31:378-85. 10.1002/art.1780310309

43. Terrier B, Tamby MC, Camoin L, et al.: Antifibroblast antibodies from systemic sclerosis patients bind to \{alpha\}-enolase and are associated with interstitial lung disease. Ann Rheum Dis. 2010, 69:428-33. 10.1136/ard.2008.104299

44. Chizzolini C, Raschi E, Rezzonico R, et al.: Autoantibodies to fibroblasts induce a proadhesive and proinflammatory fibroblast phenotype in patients with systemic sclerosis. Arthritis Rheum. 2002, 46:160213. 10.1002/art.10361

45. Perelas A, Silver RM, Arrossi AV, Highland KB: Systemic sclerosis-associated interstitial lung disease . Lancet Respir Med. 2020, 8:304-20. 10.1016/S2213-2600(19)30480-1

46. Nihtyanova SI, Schreiber BE, Ong VH, et al.: Prediction of pulmonary complications and long-term survival in systemic sclerosis. Arthritis Rheumatol. 2014, 66:1625-35. 10.1002/art.38390

47. Moore OA, Proudman SM, Goh N, et al.: Quantifying change in pulmonary function as a prognostic marker in systemic sclerosis-related interstitial lung disease. Clin Exp Rheumatol. 2015, 33:S111-6.

48. Li Q, Wallace L, Patnaik P, et al.: Disease frequency, patient characteristics, comorbidity outcomes and immunosuppressive therapy in systemic sclerosis and systemic sclerosis-associated interstitial lung disease: a US cohort study. Rheumatology (Oxford). 2021, 60:1915-25. 10.1093/rheumatology/keaa547

49. Behr J, Furst DE: Pulmonary function tests. Rheumatology (Oxford). 2008, 47 Suppl 5:v65-7. 10.1093/rheumatology/ken313

50. Tashkin DP, Roth MD, Clements PJ, et al.: Mycophenolate mofetil versus oral cyclophosphamide in scleroderma-related interstitial lung disease (SLS II): a randomised controlled, double-blind, parallel group trial. Lancet Respir Med. 2016, 4:708-19. 10.1016/S2213-2600(16)30152-7

51. Giacomelli R, Liakouli V, Berardicurti O, et al.: Interstitial lung disease in systemic sclerosis: current and future treatment. Rheumatol Int. 2017, 37:853-63. 10.1007/s00296-016-3636-7

52. Showalter K, Hoffmann A, Rouleau G, et al.: Performance of forced vital capacity and lung diffusion cutpoints for associated radiographic interstitial lung disease in systemic sclerosis. J Rheumatol. 2018, 45:1572-6. 10.3899/jrheum.171362

53. Sánchez-Cano D, Ortego-Centeno N, Callejas JL, et al.: Interstitial lung disease in systemic sclerosis: data from the spanish scleroderma study group. Rheumatol Int. 2018, 38:363-74. 10.1007/s00296-017-3916-X

54. Distler O, Assassi S, Cottin V, et al.: Predictors of progression in systemic sclerosis patients with interstitial lung disease. Eur Respir J. 2020, 55: 10.1183/13993003.02026-2019

55. Noviani M, Saffari SE, Tan JL, et al.: Mortality and hospitalization outcomes of interstitial lung disease and pulmonary hypertension in the Singapore systemic sclerosis cohort. Semin Arthritis Rheum. 2020, 50:473-9. 10.1016/j.semarthrit.2019.11.005

56. Young A, Vummidi D, Visovatti S, et al.: Prevalence, treatment, and outcomes of coexistent pulmonary hypertension and interstitial lung disease in systemic sclerosis. Arthritis Rheumatol. 2019, 71:1339-49. 10.1002/art.40862

57. Mathai SC, Hummers LK, Champion HC, Wigley FM, Zaiman A, Hassoun PM, Girgis RE: Survival in pulmonary hypertension associated with the scleroderma spectrum of diseases: impact of interstitial lung disease. Arthritis Rheum. 2009, 60:569-77. 10.1002/art.24267

58. Elhai M, Meune C, Boubaya M, et al.: Mapping and predicting mortality from systemic sclerosis . Ann Rheum Dis. 2017, 76:1897-905. 10.1136/annrheumdis-2017-211448 